\title{
3.1 Is Social InNovation a Key to "De-Peripheralization"? Dealing with Challenges of Peripheralization on a Local Level
}

\author{
Stefanie DöRINGER \\ Institute for Urban and Regional Research, ÖAW, Vienna
}

\section{Introduction}

At the beginning, I want to sketch out how the idea of this paper developed within ARL Summer School 2017. As the paper builds upon reflections of my PhD thesis, I start with a brief overview of my thesis.

My thesis deals with economic development in peripheralized small-sized cities in Austria. From a regional economic perspective, these cities are facing selective outmigration, a loss of skilled workers, unemployment as well as declining municipal tax revenues (GIFFInger and Kramar 2012). These processes lead to a paradoxical situation for the municipalities. On the one hand, the pressure to act and to activate local potential becomes higher, on the other hand, there are only few financial and human resources left in the region. Furthermore, financial dependencies on superior political decision-makers and institutions limit the scope of action.

Given this situation, my thesis focuses on the local governance processes surrounding the economic development of peripheralized small-sized cities. Based on an explanatory research design, my aim is to analyse economic development processes from a relational perspective by focusing on public and private stakeholders and their interactions. Who are the decisive actors for economic development? What scope of action do they have in dealing with economic decline? These are the questions of my thesis, and I argue that actors, cooperations and networks on a local level are crucial for dealing with economic challenges in rural areas.

Based on this understanding that local actors and networks gain more importance in peripheralized areas, I wondered if the concept of social innovation could be a 
possibility for cities and regions for dealing with shrinkage. In peripheralized cities undergoing social and economic transitions, one might assume that there is a need for a "new combination and/or new configuration of social practices [...] with the goal of better satisfying or answering needs and problems than is possible on the basis of established practices", as HowaldT and Schwarz (2010a, p. 26) describe social innovation. Having been able to take part in the ARL Summer School 2017, thus, was an excellent opportunity to learn more about the concept and its meaning for regional development.

The aim of this paper is, to reflect critically on the potentials of social innovation for peripheralized regions and cities. Therefore, the following section initially outlines the multidimensional and relational concept of peripheralization. Section 3 discusses the social innovation in peripheries from a process-oriented perspective. To illustrate these theoretical considerations, a social innovation project in Austria is presented in section 4. Finally, section 5 provides some conclusions.

\section{The concept of peripheralization - how peripheries are socially produced}

Socio-economic inequalities have become increasingly apparent on different spatial scales in Europe. Processes of economic decline and out-migration raise disparities from a national, but also from a regional perspective (European COMMISSION 2014). KÜHN (2015) explains these processes with the term peripheralization. This theoretical approach describes the development of peripheries: Peripheries are no longer only spatially determined, but emerge through dynamic and socio-spatial processes (Copus 2001, KeIM 2006, KüHN and WeCK 2013). According to KÜHN (2015) peripheralization can be understood as the production of peripheries through social relations and their spatial implications.

The concept of peripheralization is multidimensional as it starts from three theoretical perspectives: economic polarization, social inequality and political power. Following up on this, the process of peripheralization considers social, economic, political and communicative dimensions. From a social perspective, peripheralized areas are facing selective out-migration and ageing. Furthermore, rural areas have been often mono-industrially oriented and are thus strongly affected by deindustrialization processes and increasing unemployment rates. The political perspective points out to the limited scope of action by local actors due to a lack of power in superior decision-making processes and financial cutbacks. As municipal tax revenues and financial resources drop drastically in these areas, there are growing difficulties to maintain local infrastructures. Among these, peripheralized areas suffer often from two-fold stigmatization process: an internal process by the residents themselves; and an external process, for instance, driven by media or press (BEETz et al. 2008, KеIM 2006). 
It is important to emphasize that these developments can have a self-reinforcing dynamic, but do not necessarily cause a general downward spiral in the affected cities and municipalities (KüHN 2015). Peripheralization offers also economic and social opportunities, rather than simply creating societal problems. Therefore, the concept points to possibilities of "de-peripheralization", in which municipalities manage to overcome innovation weakness and economic and political dependencies (KÖHLER 2012). In this context, many authors (e.g. Troeger-Weiss 2008, WeCK and Beisswenger 2014) highlight the importance of negotiation and cooperation processes in local governance arrangements.

However, so far the debates on coping strategies for shrinking regions have primarily focused on technological innovations and redefining top-down planning standards (BEETZ et al. 2008). Forms of participation and civil society mobilization are still underrepresented aspects in the discourse. I argue that innovation, defined as a social process that highly depends on regional or local cooperation and networks, should receive more attention from scientists and policy-makers. Mutual learning and communication between local actors of politics, economy and civil society are decisive factors for activating endogenous potentials (TöDTLING 2010) and dealing successfully with peripheralization processes.

\section{The process of social innovation in peripheralized regions and cities}

\section{A process-oriented definition of social innovation}

Although many authors agree that social innovation opens new perspectives for regional development (MoulaerT and MEHMOOD 2011), little attention has been paid to social innovation and its underlying mechanisms in regional research (NeumeIER 2012). Against the background of regional development, I follow a process-oriented definition (Grimm et al. 2013). Among others, Howaldt and Schwarz (2010b) take a process-oriented perspective and outline the relevance of actors and actor networks for the solution of problems:

"A social innovation is new combination and/or new configuration of social practices in certain areas of action or social contexts prompted by certain actors or constellations of actors in an intentional targeted manner with the goal of better satisfying or answering needs and problems than is possible on the basis of established practices." (Howald and Schwarz 2010a: 18)

NeumeIER also draws on an actor-based definition and states that social innovations are "changes of attitudes, behaviour or perceptions of a group of people joined in a 
network of aligned interests that, in relation to the group's horizon of experiences, lead to new and improved ways of collaborative action within the group and beyond." (2012, p. 15) According to NEUMEIER (2012), in terms of regional development improvements can occur in the field of economic performance, living conditions or public good. He further stresses that social innovation is not only about meeting social needs, but also about asset building and community development in general (NEUMEIER 2017). Considering a long-term perspective in context of de-peripheralization processes, this is an important insight.

Furthermore, Neumeier (2012) suggests a process model (see Fig. 1) that includes three stages of social innovation:

- Problematization: At this stage, a single actor or a group of actors identify a problem and articulate a desire for change or a social need. The impetus triggering this perception can be internal or external. The awareness leads to a formation of a group of actors trying to find a solution for the defined need.

- Expression of interest: The initiators make the idea public. If the idea satisfies other actors, these actors begin to join the core group and adopt the idea.

- Delineation and co-ordination: The actor network with a common interest negotiates the collaborative actions. Mutual learning processes take place and the new action is formed incrementally. If a critical number of actors accept the new form of collaborative action, the social innovation has been successfully implemented.

This model demonstrates that the process of social innovation is an important outcome of the innovation itself. As social innovation is not purely target-oriented, participation, cooperation and interaction are inseparable from the social innovation process (Grimm et al. 2013).

\section{Social innovation in the periphery: Social needs, potentials and barriers}

The previous definition of Howald and Schwarz (2010a) showed that social innovation aims on "better satisfying or answering needs and problems". However, what society recognizes as social need is context specific and the result of societal negotiation processes between different groups of actors. As outlined in section 2, peripheralized areas are facing challenging demographic and economic developments. Derived from these developments, the table below lists social needs that require special attention in peripheralized areas. 
Figure 1: Process of social innovation, Neumeier 2017: 36

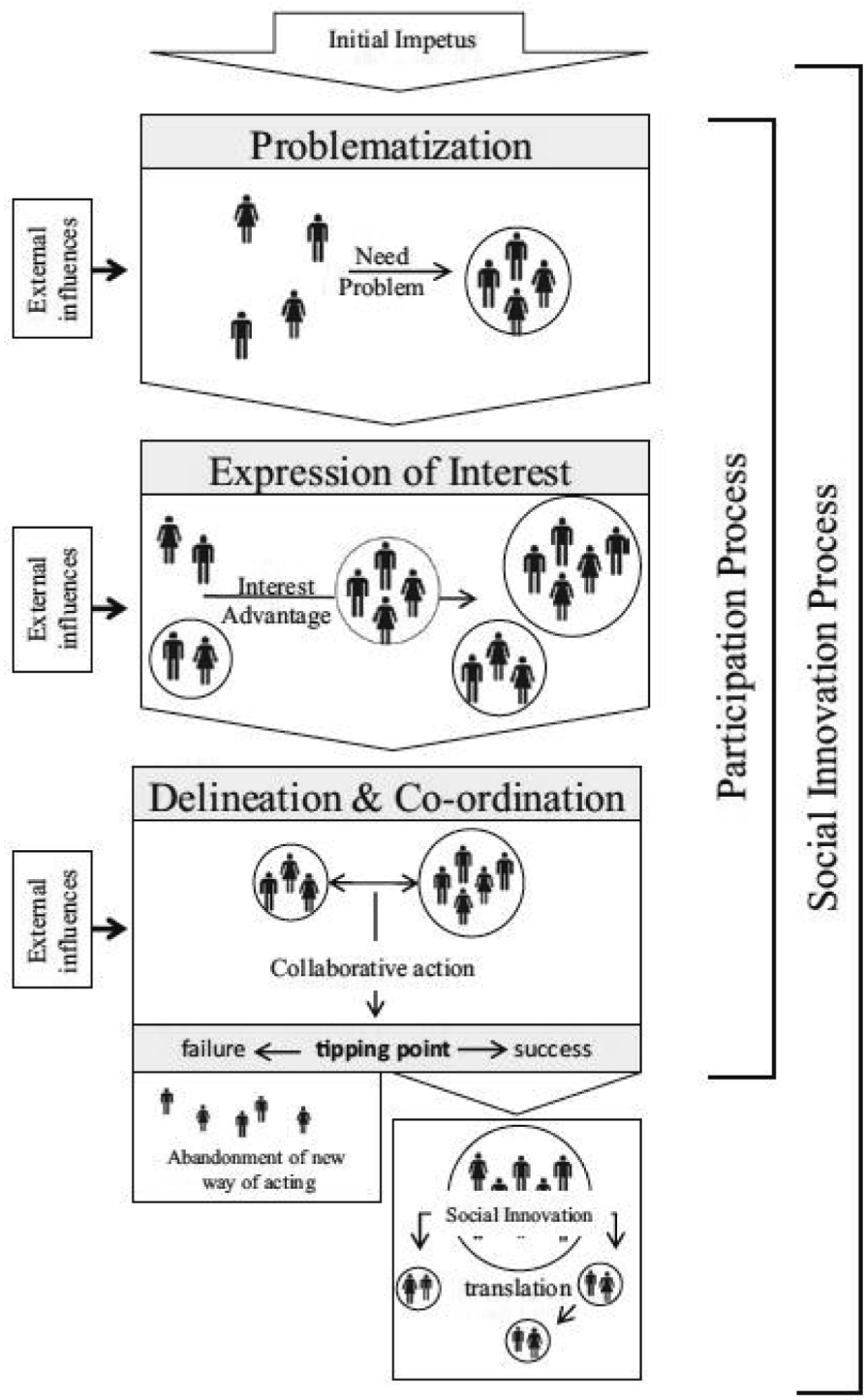

中t) Single actors

(A) Group of actors joined in a network of aligned interests

Exchange of thoughts, know-how, skills;

$\searrow$ mutual learning 
Table 1: Challenges by peripheralization and evolving social needs

\begin{tabular}{|l|l|l|}
\hline Dimensions & \multicolumn{1}{|c|}{ Challenges of peripheralization } & \multicolumn{1}{c|}{ Social needs } \\
\hline Social & $\begin{array}{l}\text { (Selective) out-migration and ageing } \\
\text { Decoupling of social and technical } \\
\text { infrastructures } \\
\text { Stigmatization through internal/ } \\
\text { external processes }\end{array}$ & $\begin{array}{l}\text { Participation (e.g. of older people) } \\
\text { Social services (health, education, } \\
\text { childcare, long-term services), } \\
\text { mobility } \\
\text { Individual and collective self- } \\
\text { awareness }\end{array}$ \\
\hline Economic & $\begin{array}{l}\text { Decline of employment } \\
\text { (deindustrialization) }\end{array}$ & Security of employment, identity \\
\hline Political & $\begin{array}{l}\text { Dependency from government } \\
\text { transfers } \\
\text { Dependency from external decision- } \\
\text { makers }\end{array}$ & Self-determination and empowerment \\
\hline
\end{tabular}

Traditional strategies of regional development are often considered as insufficient or inadequate in terms of meeting social needs in the periphery. At grassroots level, citizens can target social needs in a new way by creating personalized and flexible solutions. Demographic change, economic transformation and political dependencies lead to changing social needs that require creative approaches.

As shown, there is a need for social innovation in the periphery. But what can promote or hamper social innovation in the periphery? Aside from the general willingness to meet social needs, the social capital of actors has been identified as a key to innovation (GRIMm et al. 2013). In terms of quantity, one must admit that it is easier for urban agglomerations or metropolitan areas to reach the critical mass of actors required to encourage social innovation. However, social proximity, for instance, can have the positive effect for creating social capital and enabling social innovation in rural communities. Boschma (2005) argues that social proximity based on trust in friendship or kinship encourages a social and open attitude of communication between actors. HowaldT and Schwarz (2010b) consider the exchange of explicit and implicit knowledge in social networks crucial for the success of social innovation. A strong community awareness based on networking and trust can thus trigger social innovation processes (Boschma 2005).

However, a critical issue concerning the implementation of social innovation in peripheralized areas is the lack of financial resources. When individuals or a small group of people come up with new ideas, bigger organizational and financial support will be needed to realize the project. A well-known EU-program is LEADER, which supports rural development projects initiated at the local level (BOSWORTH et al. 2016). Although programs from superior levels that support bottom-up approaches in regional development do exist, there is a need to expand external support, which addresses the different character of regions. 
To illustrate participation and innovation processes against the background of peripheralization, section 4 provides a case example of social innovation in a small-sized city in Austria. As the focus lies on the participation process, the model of NeUMEIER (2012) provides the conceptual framework for the following case study.

\section{Social innovation in an old-industrial town in Austria}

\section{Economic and demographic development of Eisenerz}

Former industrial regions experiencing structural change are the dominating type of shrinking areas in Austria. In these regions, small-sized cities are important centers of public administration, education and labour. The small-sized city of Eisenerz (about 4.200 residents) is a representative example of areas affected by deindustrialization in the last century. Located in the mountains of Upper Styria, the city's economy was largely based on the extraction of iron from the Erzberg. Related to the structural change in the second half of the 20th century, Eisenerz's economic base was undermined. The unemployment rate increased and the old industrial town lost two thirds of its population over the last three decades (Statistics Austria 2017). Due to the overlap of selective out-migration of young people and a decreasing fertility rate, Eisenerz has one of the oldest populations in Austria to date.

Figure 2: New paths for old industrial towns through social innovation? Eisenerz, Upper Styria, author's photo, 2014

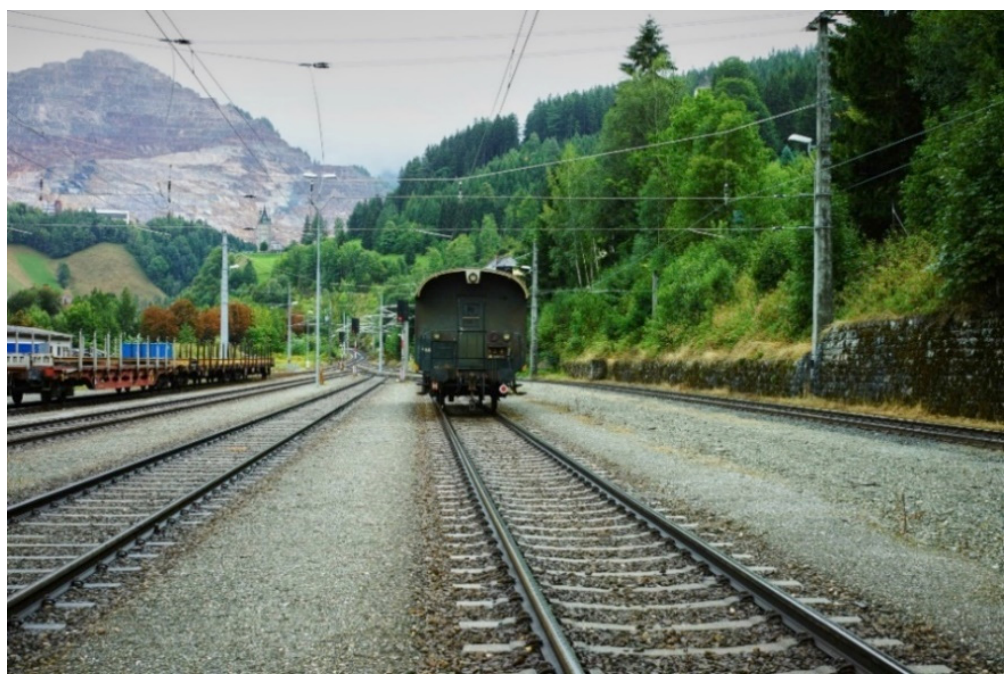




\section{The "Rostfest" - Social innovation in Eisenerz}

The old industrial town did not give in to fate, but decided to cope actively with shrinkage by implementing the strategic planning concept "re-design Eisenerz 2021" in the year 2006 (RE-DESIGN EISENERZ 2021). In addition, a small group of actors involved in the process of "re-design Eisenerz 2021" developed the idea of a non-profit festival for music and the arts in Eisenerz, the "Rostfest"1. Supported by a local arts initiative the socio-cultural festival first took place in the year 2012. Based on the initiators' experience and knowledge about the situation in Eisenerz, the festival faces the challenges of shrinkage in a creative but also sustainable way. The aim of the annual festival is, to develop alternative forms of economy and social life in shrinking regions in a smallscaled, integrative and participatory process (rostfest.at; netzwerk-land.at).

The festival draws on a large network of public and private actors. Contrary to traditional forms of participation, residents are directly involved in activities concerning the organization and realization of the Rostfest. The implementation is largely based on the commitment of local and regional volunteers ("helping hands"). Moreover, the Rostfest cooperates with research institutes to discuss perspectives of shrinking regions in a broader context and to create spin-off effects. As there is no admission fee, the festival depends on funding from national, regional and local public authorities and organisations. The LEADER Region "Steierische Eisenstrasse", for instance, is an important stakeholder and provides a large part of the financial resources. Additionally, private local and regional enterprises support the festival with donations, and the Rostfest draws on crowd funding: People can purchase "Rostanteile" to support the festival (rostfest.at; netzwerk-land.at).

Culture is a central aspect of the festival, and a broad range of exhibitions, concerts and performances take place throughout the city. The festival focuses on reusing vacant properties and valuing them as resources. For instance, vacant ground floors in the inner city serve as locations for events during the Rostfest. About 60 years ago, 4.000 residents lived in the former worker's housing estate "Münichtalsiedlung", which today is mostly abandoned. During the festival the vacant apartments are re-used for "urban camping". The alternative "campsite" provides not only accommodation space for the festival visitors, but also space for laboratories and experimental workshops with different actors (external and residents) that deal with alternative forms of housing (rostfest.at). Additionally, the festival website aims at raising public awareness of the city and the festival, for instance, by offering the opportunity to create individual digital postcards (see Fig. 3).

The festival targets the social needs of peripheralized areas in a multifaceted way. Due to its integrative form, the festival is a novelty in its spatial context. Following the above mentioned definition, the festival can be classified as a social innovation. The

1 The name of the festival refers to the long history of steel production and the associated "rust". 


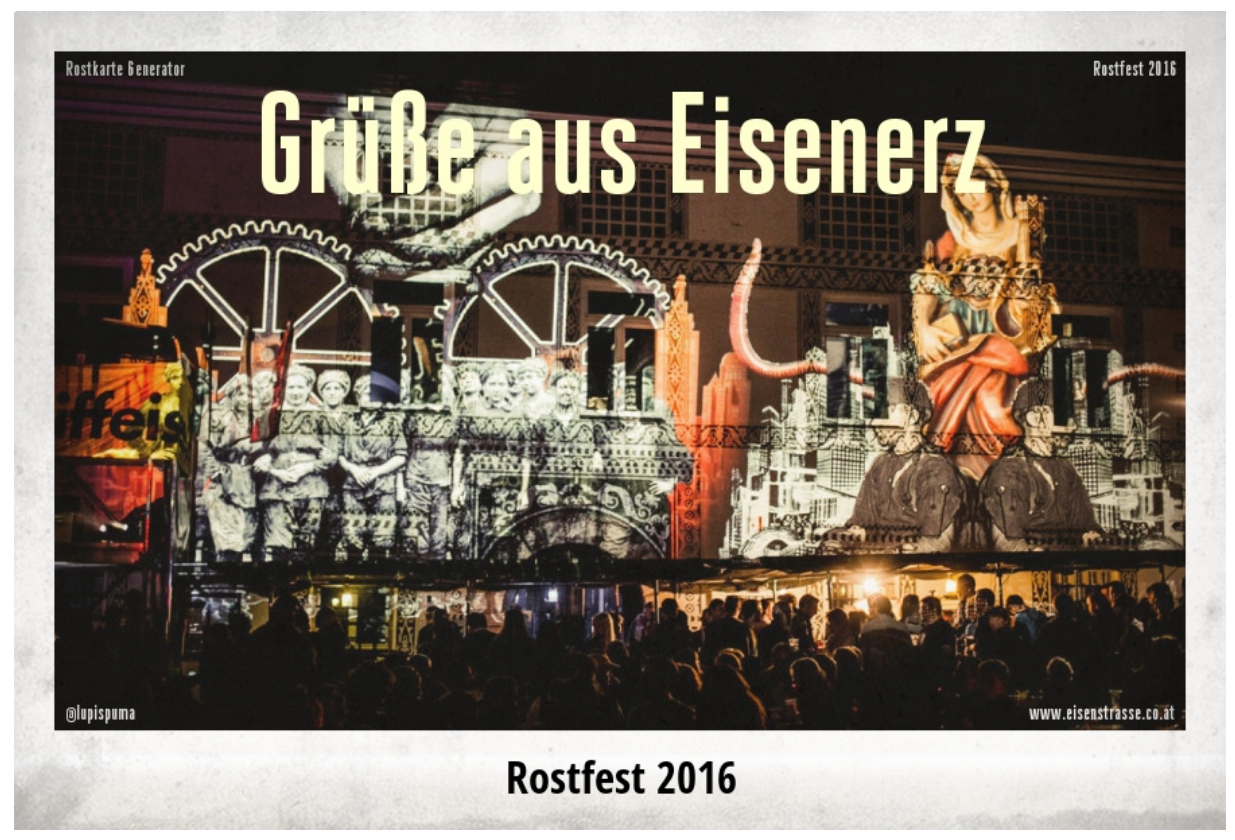

idea of a socio-cultural festival bridges social and economic aims and inspires new entrepreneurship. The Rostfest also shifts the attention to demographic challenges and encourages interaction between the elderly population of Eisenerz and young festival visitors. Furthermore, it addresses processes of external and internal stigmatization under which Eisenerz has suffered for many decades. Through visitors and the media, a positive image of Eisenerz is conveyed across the region's boundaries, which also influences the self-perception of the residents positively. Nevertheless, critics might claim that the festival only bears short-term effects. But on the contrary, sustainability is a central element of the festival, and changes in attitude toward shrinking regions and the sustainable empowerment of local residents are central concerns of the festival team.

The Rostfest can be positively identified as bottom-up project. The social capital and the engagement of the civil society as well as the network of the organisation team are decisive for the successful implementation of this social innovation. What becomes obvious is how important the financial support from public and private actors are for social innovation projects in peripheralized areas. However, it becomes increasingly difficult to receive public funding for bottom-up projects in peripheral regions (rostfest. at). 


\section{Social innovation as a key to "de-peripheralization"?}

The social innovation concept seems to be a fruitful alternative approach for regional development and can be considered an important contribution for dealing with peripheralization processes. The concept sheds light on the social capital of peripheries and shows that the local and regional actors are not powerless when faced with peripheralization. As shown in the case study, social innovation can enhance the quality of life for citizens in peripheralized areas. In the long-term, social innovation supports the sustainable empowerment and the capacity building of individual citizens. These are both important resources for coping with emerging challenges in the future. Furthermore, the participation of individual citizens in regional development provides a necessary basis for policy-makers to develop flexible approaches tailored to their localities.

By fostering engagement and participation, social innovation ushers the responsibility into the field of civil society. Against the background of increasing spatial disparities, traditional practices of regional development, based mainly on public actors, can no longer sufficiently cope with present-day challenges. Empowerment of citizens has therefore become particularly attractive when confronting the growing and diverse needs of society. However, the engagement of the third sector is not the solution of a neo-liberal agenda that transfers the public obligations to the individual citizens. The public sector has an important role to play in social innovation processes by providing financial and institutional incentives and by removing barriers that are in the way of a successful implementation of social innovation.

As mentioned in the beginning, my explorative $\mathrm{PhD}$ thesis focuses on public and private actors in economic development against the background of shrinkage. The concept of social innovation helped me extend my research perspective by shedding light on the importance of bottom-up approaches and the role of individual citizens for regional development. Although I do not explicitly focus on social innovation in my thesis, I am convinced that the concept plays a key role for the regional development of peripheralized areas in the future. As social innovation in the periphery is still underrepresented in research, more theoretical and empirical work is needed to understand how societal processes of change can emerge in regional development. Finally, it is necessary to deepen the scientific debate in order to shape policy measures that adequately support bottom-up initiatives. 


\section{References}

Beetz S., Huning S., \& Plieninger T. (2008), Landscapes of Peripherization in North-Eastern Germany's Countryside: New Challenges for Planning Theory and Practice. International Planning Studies 13, pp. 295-310.

Boschma R. (2005), Proximity and Innovation: A Critical Assessment. Regional Studies 39, pp. $61-74$

Bosworth G., Annibal I., Carroll T., Price L., Sellick J., \& Shepherd J. (2016), Empowering Local Action through Neo-Endogenous Development; The Case of LEADER in England. Sociologia Ruralis 56, pp. 427-449.

Copus A.K. (2001), From Core-periphery to Polycentric Development: Concepts of Spatial and Aspatial Peripherality. European Planning Studies 9, pp. 539-552.

European Commission (2014), Investment for jobs and growth. Promoting development and good governance in EU regions and cities. Sixth Report on Economic, Social and Territorial Cohesion. Brussels.

GIFFIngER R., \& Kramar H. (2012), Kleinstädte als Wachstumsmotoren ländlich-peripherer Regionen: Das Beispiel Waldviertel. disP - The Planning Review 48, pp. 63-76.

Grimm R., Fox C., Baines S., \& Albertson K. (2013), Social innovation, an answer to contemporary societal challenges? Locating the concept in theory and practice. Innovation: The European Journal of Social Science Research 26, pp. 436-455.

Howaldt J., \& Schwarz M. (2010a), Social Innovation: Concepts, research fields and international trends. Aachen, Sozialforschungsstelle Dortmund.

Howaldt J., \& Schwarz M. (2010b), Soziale Innovation - Konzepte, Forschungsfelder und -perspektiven. In: Howaldt J. \& Jacobsen H. (eds.), Soziale Innovation: Auf dem Weg $z u$ einem postindustriellen Innovationsparadigma. Wiesbaden, VS Verlag für Sozialwissenschaften, pp. 87-108.

KeIm K.-D. (2006), Peripherisierung ländlicher Räume. Aus Politik und Zeitgeschichte: APuZ 37, pp. 3-7.

KöHLER S. (2012), Peripherie muss nicht Peripherie bleiben: Entperipherisierung am Beispiel der Region Bodensee-Oberschwaben. disP - The Planning Review 48, pp. 55-62.

KüHN M. (2015), Peripheralization: Theoretical Concepts Explaining Socio-Spatial Inequalities. European Planning Studies 23, pp. 367-378.

KÜHN M., \& WeCK S. (2013), Peripherisierung - ein Erklärungsansatz zur Entstehung von Peripherien. In: Bernt M. \& Liebmann H. (eds.), Peripherisierung, Stigmatisierung, Abhängigkeit? Deutsche Mittelstädte und ihr Umgang mit Peripherisierungsprozessen. Wiesbaden, Springer Fachmedien Wiesbaden, pp. 24-34.

Moulaert F., \& Mehmood A. (2011), Spaces of social innovation. In: Pike A., Rodríguez-Pose A., \& Tomaney J. (eds.), Handbook of local and regional development. London and New York, Routledge, pp. 212-225.

NeUmeier S. (2012), Why do social innovations in rural development matter and should they be considered more seriously in rural development research? - Proposal for a Stronger Focus on Social Innovations in Rural Development Research.

NeumeIER S. (2017), Social innovation in rural development: identifying the key factors of success. The Geographical Journal 183, pp. 34-46. 
TöDtling F. (2010), Endogenous approaches to local and regional. In: Pike A., Rodríguez-Pose A., \& Tomaney J. (eds.). Handbook of local and regional development. London and New York, Routledge, pp. 333-342.

Troeger-Weiss G., Domhardt H.-J., Hemesath A., Katenegger C., \& Scheck C. (2008), Erfolgsbedingungen von Wachstumsregionen außerhalb der Metropolen. Die Modellregionen und ihre Teilprojekte. In: Bundesministerium für Verkehr, Bau und Stadtentwicklung (BMVBS) \& BUNDESAMT FÜR BAUWESEN UND RAUMORDNUNG (BBR) (eds.), Werkstatt: Praxis Heft 56. Bonn.

Weck S., \& Beisswenger S. (2014), Coping with Peripheralization: Governance Response in Two German Small Cities. European Planning Studies 22, pp. 2156-2171.

\section{Online References}

NeTZwerk LAND. LEADER 07-13. Magazin für ländliche Entwicklung. 2. 13:

http://www.netzwerkland.at/lum/downloads/ausblicke-magazin-fuer-laendlicheentwicklung/ausblicke-2.13-zeit/le_magazine _zeit_medium.pdf/at_download/file [Last accessed on 27-11-2017]

Re-Design EIsenerz 2021! Erstellung eines Maßnahmenkataloges zur Verbesserung der Wohnsituation in Eisenerz:

http://www.wohnbau.steiermark.at/cms/dokumente/12117673_113 384051/728d755a/ eisenerz.pdf [Last accessed on 27-11-2017]

Rostfest. Festival für regionale Impulse. Dokumentation 2014:

http://rostfest.at/2015/wpcontent/uploads/rostfest-doku_v5_screen.pdf [Last accessed on 27-11-2017]

Statistics Austria. Blick auf die Gemeinde. Eisenerz:

http://www.statistik.at/blickgem/blick1/g61101.pdf [Last accessed on 27-11-2017]

\section{List of Figures and Table}

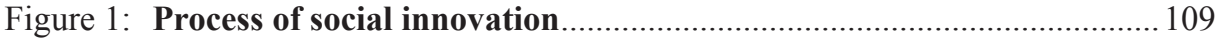

Figure 2: New paths for old industrial towns through social innovation?

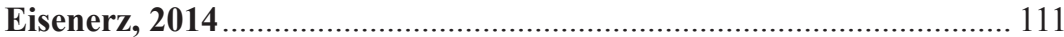

Figure 3: Digital postcard "Rostkarte" of Rostfest 2016 ................................. 113

Table 1: Challenges by peripheralization and evolving social needs ................. 110 